\title{
Diversity, biomass, covers, and NDVI of restored mangrove forests in Karawang and Subang Coasts, West Java, Indonesia
}

\author{
AGUNG SUWANTO ${ }^{1, \bullet}$, NOVERITA DIAN TAKARINA ${ }^{2}$, RALDI H KOESTOER ${ }^{1}$, EVI FRIMAWATY ${ }^{1}$ \\ ${ }^{1}$ School of Environmental Science, Universitas Indonesia. Jl. Salemba Raya No. 4, Kampus UI Salemba, Jakarta Pusat 10430, Jakarta, Indonesia. \\ vemail: agung.suwanto1@gmail.com \\ ${ }^{2}$ Department of Biology, Faculty of Mathematics and Natural Sciences, Universitas Indonesia. Jl. Lingkar UI, Depok16424, West Java, Indonesia
}

Manuscript received: 4 July 2021. Revision accepted: 31 August 2021.

\begin{abstract}
Suwanto A, Takarina ND, Koestoer RH, Frimawaty E. 2021. Diversity, biomass, covers, and NDVI of restored mangrove forests in Karawang and Subang Coasts, West Java, Indonesia. Biodiversitas 22: 4115-4122. Indonesia has been recognized as the country with greatest diversity of mangrove species with significant amount of carbon sink and biomass. In few recent decades, mangrove forests have been deforested significantly. One of the solutions to deal with mangrove deforestation is through restoration. West Java north coasts are one of the areas that have experienced deforestation, however, and mangrove restorations have been conducted mainly in Karawang and Subang coasts. Correspondingly this research aims to assess the mangrove diversity using index and biomass resulted from restoration programs in those coasts. To assess the mangrove diversity in each coast on June 2021, 6 sampling stations containing 3 replicated sample plots of size $10 \mathrm{~m} \times 10 \mathrm{~m}$ were located. In total 8 species with 1549 trees were been sampled. In Subang the order of mangrove species from common to less-common species was Avicennia marina > Rhizophora mucronata $>$ Sonneratia caseolaris $>$ Acanthus ilicifolius $>$ Bruguiera gymnorhiza. While the order in Karawang was Avicennia marina $>R$. mucronata $>$ Rhizophora apiculata $>$ S. caseolaris $>$ B. gymnorhiza. The mangrove diversity $(\mathrm{H})$ ' was significantly different $(\mathrm{p}=0.000$, $\mathrm{F}=2.216$ ) with diversity in Subang Coast (average $\mathrm{H}^{\prime}=1.326,95 \%$ CI: $1.15-1.5$ ) was higher than in Karawang (average $\mathrm{H}^{\prime}=1.063$, 95\%CI: 0.934-1.2). Estimated restored mangrove covers in Subang were $3.612 \mathrm{~km}^{2}$ and $0.46 \mathrm{~km}^{2}$ in Karawang. R. mucronata was a mangrove species with the highest biomass with the value of $1337.91 \mathrm{mg} \mathrm{ha}^{-1}$ and the lowest was A. marina with a value of $14.3 \mathrm{mg}^{-}$ ${ }^{1}$. The results suggest that restoration areas in Subang and Karawang have significant contributions to maintain mangrove diversity, biomass, and covers.
\end{abstract}

Keywords: Allometric model, biomass, dominance, mangrove diversity, NDVI, restoration, Shannon-Wiener index

\section{INTRODUCTION}

Mangrove forest area in Indonesia was estimated to be $3,112,989$ ha or $22.6 \%$ of the total mangrove area globally (Giri et al. 2011). Mangrove forests alone have important biological wealth for Indonesia's coastal areas considering that mangrove forest is a transitional ecosystem in almost all coastal areas in the Indonesian Archipelago, ranging from Sumatra in the West to Papua Islands in the East. Despite the fact that mangroves cover such a huge area, Indonesia has 47 true mangrove species (Yudha et al. 2021), representing a higher species diversity than other countries in Southeast Asia.

Despite biodiversity, one of important parameters to evaluate mangrove assemblage is biomass. Mangrove biomass and their productivity are the two important parameters for indicating the material and nutrient inputs in the mangrove ecosystem. Consequently, many studies have developed biomass estimation methods for mangroves, including harvest, mean-tree, and allometric methods. This method is the most frequently used to estimate the mangrove forests biomass based on the diameter of mangrove tree trunks. Allometric models for mangroves biomass estimation vary greatly among the species and sites. In Panabo Park, Philippines, Alimbon and Manseguiao (2021) have measured the biomass for
Avicennia marina, Rhizophora mucronata and Sonneratia alba of $46.30 \mathrm{mg} \mathrm{ha}^{-1}, 2.89 \mathrm{mg} \mathrm{ha}^{-1}$ and $27.98 \mathrm{mg} \mathrm{ha}^{-1}$ respectively. In the study of Analuddin et al. (2020), the measured $R$. stylosa biomass in Southeast Sulawesi ranged from 21.19 to $562.76 \mathrm{mg} \mathrm{ha}^{-1}$. While, Zulhalifah et al. (2021), have recorded the biomass for A. marina, Rhizophora apiculata and Sonneratia caseolaris of 36.72 $\mathrm{mg} \mathrm{ha}^{-1}, 148.92 \mathrm{mg} \mathrm{ha}^{-1}$, and $127.76 \mathrm{mg} \mathrm{ha}^{-1}$ respectively in Lombok.

Numerous assessments on mangrove biodiversity and biomass were already implemented, whereas, only a few studies were conducted in the North of West Java Coasts. At the same time, mangroves on this coast were experiencing ongoing deforestation. Sodikin et al. (2017) have shown that mangrove areas in Indramayu Coast, West Java were decreased by 2.345 ha and the worst damage was recorded in Cantigi areas. One of the solutions to mitigate deforestation in West Java is through restoration. In West Java, coastal restoration activities by mangrove planting have been started since 1990. From 1999 to 2003, these activities resulted in 7.890 ha restored mangrove areas whereas the success rate was still very low. Based on this result, the rate of mangrove forest restoration in West Java

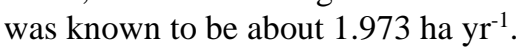

Karawang and Subang were mid areas in West Java that were also experiencing deforestation. Realizing this 
condition, several restoration activities initiated by government and community have been conducted through mangrove seedling plantings. This research was aimed to evaluate the results of mangrove restoration in Karawang and Subang Coasts based on diversity, biomass, land covers and NDVI variables.

\section{MATERIALS AND METHODS}

\section{Study area}

The study was conducted in June 2021 in Tangkolak, Karawang District and Blanakan, Subang District of West Java Province, Indonesia. Tangkolak (Karawang) has a size of $7.32 \mathrm{~km}^{2}$ and surrounded by mangrove forests on its northern coast. Fishponds dominated southern part of Tangkolak (Karawang). Blanakan (Subang) was located in the East of Tangkolak and it has area of $5.22 \mathrm{~km}^{2}$. The mangrove forest in Blanakan (Subang) was restored by the community through mangrove seedling plantings inside the fish ponds.

\section{Procedures}

Mangrove diversity, density and dominance

Method to assess mangrove forest diversity was modified from Dangan-Galon et al. (2016) and Sreelekshmi et al. (2020) based on the transect method on direct observation in mangrove restoration areas Blanakan (Subang) and Tangkolak (Karawang) coasts. On each coast on June 2021, six sampling stations containing 3 replicated sample plots sizing $10 \mathrm{~m} \times 10 \mathrm{~m}$ were located. Inside the $10 \mathrm{~m} \times 10 \mathrm{~m}$ plot, mangrove species and numbers of mangrove trees with a trunk diameter (Diameter at Breast Height/DBH) $\geq 10 \mathrm{~cm}$ and height $\geq 1.5 \mathrm{~m}$ were recorded. The density was measured as numbers of trees within 1 ha and denoted as trees ha ${ }^{-1}$.

The mangrove diversity was assessed using ShannonWiener ( $\mathrm{H}^{\prime}$ ) and Dominance (D') indices (Asuk et al. 2018; Rahmayanti et al. 2018; Kasim et al. 2019). The H' was calculated as follows:

$$
\mathrm{H}^{\prime}=\Sigma[\mathrm{Pi} \ln (\mathrm{Pi})]
$$

Where: $\mathrm{Pi}$ is the proportion of the species i mangrove in total individuals. The $\mathrm{H}^{\prime}$ range is from 0 (low diversity) to 1 (high diversity).
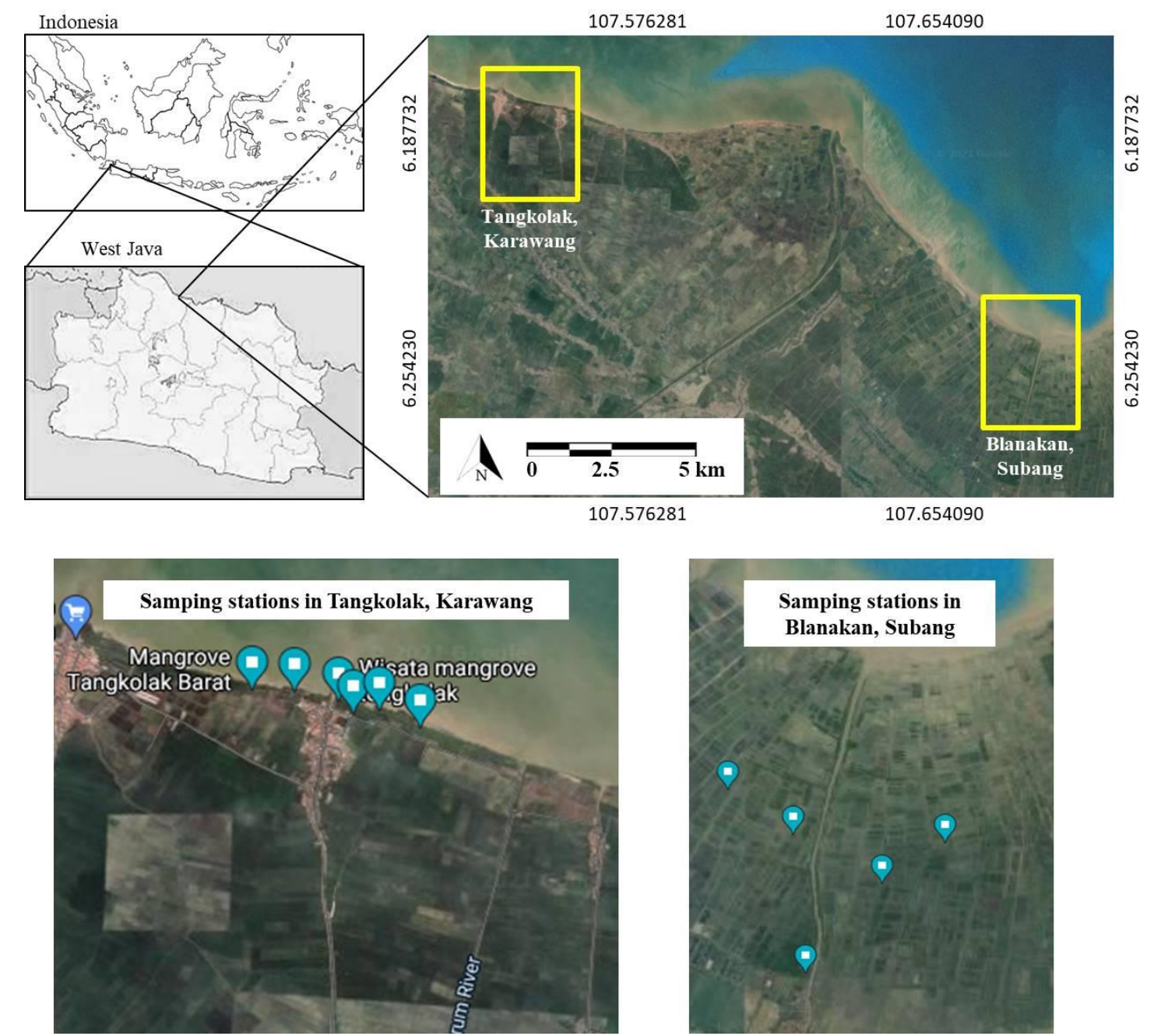

Figure 1. Map of study area and sampling stations in Tangkolak, Karawang and Blanakan, Subang Coasts, West Java. In each study area, 6 stations with 3 replicated $10 \mathrm{~m} \times 10 \mathrm{~m}$ sampling plots were located 
The D' was calculated following:

$\mathrm{D}^{\prime}=1-[(\Sigma \mathrm{i}$ ni $($ ni-1)/N $(\mathrm{N}-1)]$,

Where: ni is the number of the species i mangrove in total individuals $(\mathrm{N})$.

\section{Mangrove cover and NDVI}

Mangrove cover classification was performed using Geographical Information System (GIS) analysis. A Landsat 8 satellite imagery (Landsat 8 Operational Land Imager (OLI) acquisition date: June, 24 2021) was retrieved and classified using supervised classification to determine the land cover types. The categories for land cover classifications were mangrove, settlement, ponds, and water. The sizes of each land cover category were measured to determine the land cover compositions denoted as percentage (\%).

The method to measure mangrove NDVI was modified from Alatorre et al. (2016), Ibharim et al. (2015), and Rhyma et al. (2020). The NDVI is described as a simple graphical indicator that can be used to analyze remote sensing measurements, often from a space satellite platform, assessing whether the observed target contains live green vegetation. The NDVI was measured by analyzing the wavelength of satellite images retrieved from Landsat 8 containing vegetation images, which was mangrove in this study. This measurement is possible since cell structure of the vegetation leaves strongly reflects nearinfrared light wavelength ranges from 0.7 to $1.1 \mu \mathrm{m}$. The calculation of NDVI for each pixel of vegetation pixel was as follows:

NDVI = near-invisible red wave length-red wavelength / near-invisible red wavelength + red wavelength

The NDVI was denoted as 0 (no vegetation) to 1 (high vegetation density). The NDVI rasters were then overlayed into Blanakan (Subang) and Tangkolak (Karawang) land cover layers using GIS. The mangrove covers are then categorized and classified by using NDVI as follows (Hanan et al. 2020):

if $0<\mathrm{NDVI}<0.32$ then mangrove covers $<50 \%$ if $0.32<\mathrm{NDVI}<0.43$ then mangrove covers are $50-69 \%$ if $0.43<\mathrm{NDVI}<1.0$ then mangrove covers are $70-100 \%$

\section{Mangrove biomass}

The mangrove biomass for each recorded species was calculated using allometric methods. In this method, allometric models were established using independent variables of DBH. The allometric models for biomass estimation of each species were available in Table 1 (Clough and Scott 1989; Comley and McGuinness 2005; Analuddin et al. 2018; Kusmana et al. 2018).

\section{Data and statistical analysis}

The analysis was using ANOVA test with significant values $\mathrm{p}<0.05$. This test was used to measure the significant differences in mangrove density, diversity, and biomass between restoration areas in Tangkolak (Karawang) and Blanakan (Subang) coasts.
Table 1. Allometric model for mangrove species

\begin{tabular}{ll}
\hline Species name & Allometric model \\
\hline Avicennia marina & $0.308(\mathrm{DBH})^{2.11}$ \\
Rhizophora mucronata & $0.143(\mathrm{DBH})^{2.52}$ \\
Sonneratia caseolaris & $0.258(\mathrm{DBH})^{2.28}$ \\
Bruguiera gymnorhiza & $0.186(\mathrm{DBH})^{2.31}$ \\
\hline
\end{tabular}

\section{RESULTS AND DISCUSSION}

\section{Mangrove diversity and density}

Mangrove in Blanakan (Subang) and Tangkolak (Karawang) coasts was remarkably different (Table 2). Mangroves of Blanakan (Subang) were more diverse with 6 species from 5 families. While in Tangkolak (Karawang) there were only 5 mangrove species from 3 families. $R$. apiculata was absent in Blanakan (Subang) while Acanthus ilicifolius and Terminalia catappa were absent in Tangkolak (Karawang). In Blanakan (Subang) the order of mangrove species from common to less common species was A. marina $>R$. mucronata $>S$. caseolaris $>$ A. ilicifolius $>$ B. gymnorhiza. While the order in Tangkolak (Karawang) was A. marina $>$ $R$. mucronata $>R$. apiculata $>S$. caseolaris $>B$. gymnorhiza. All the mangrove tree species in Subang and Karawang were categorized as the least concern (IUCN 2021). Figure 2 presents the rarefaction curves. The curve demonstrated that the observed mangrove species richness tends to increase as observed in Subang and Karawang, indicating that further sampling would recover more mangrove species.

Figure 3 shows the average density of each mangrove species in every hectare in Blanakan (Subang) and Tangkolak (Karawang) coasts. In total the mangrove density in Karawang was higher. Despite having only 5 species, the mangrove density in Karawang was 5188.9 trees ha $^{-1}$ which was higher than Subang with only 3416.7 trees ha ${ }^{-1}$ yet had 6 species. In both locations, A. marina and $R$. mucronata were the most common species. Figure 4 presents the diversity and dominance index. The mangrove diversity $(\mathrm{H})$ ' was significantly different $(\mathrm{p}=0.000, \mathrm{~F}=$ 2.216) with diversity in Subang coast (average $\mathrm{H}^{\prime}=1.326$, 95\% CI: 1.15-1.5) was higher than in Karawang (average $\mathrm{H}^{\prime}=1.063,95 \%$ CI: 0.934-1.2).

\section{Mangrove covers and NDVI}

Figure 5 shows the land cover distribution and compositions in study areas. In Karawang, restored mangrove areas were fragmented and available only on the coasts. The restoration areas were bordered directly with settlements and fishponds in the south parts. These conditions were very different compared to Blanakan (Subang). Here, mangrove restoration areas were distributed and mixed with the fishponds. As a result of restoration mangrove implemented inside the ponds, the land cover composition (Figure 6) order in Blanakan (Subang) was in order of mangrove > settlement > pond. While in Tangkolak (Karawang), the order was pond $>$ mangrove $>$ settlement. Estimated restored mangrove covers in Subang were 3.612 $\mathrm{km}^{2}$ and $0.46 \mathrm{~km}^{2}$ in Karawang. 

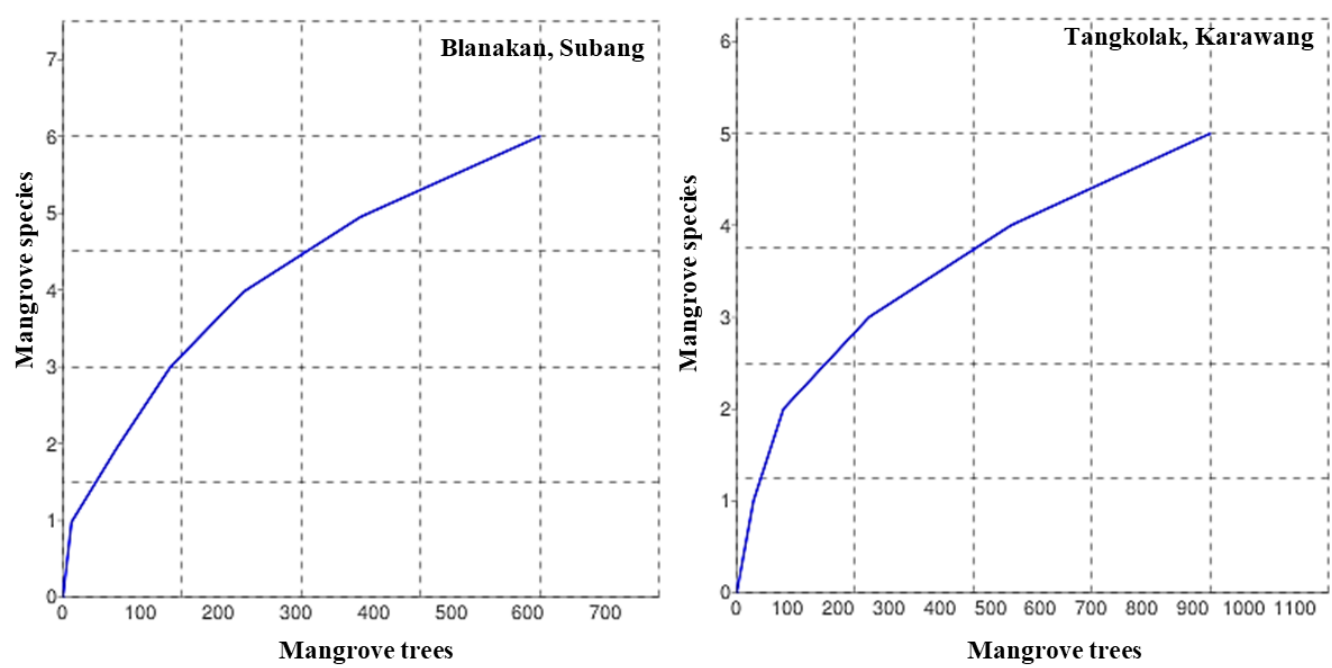

Figure 2. Rarefaction curve of mangrove species and total numbers of trees in Blanakan, Subang and Tangkolak, Karawang, West Java, Indonesia

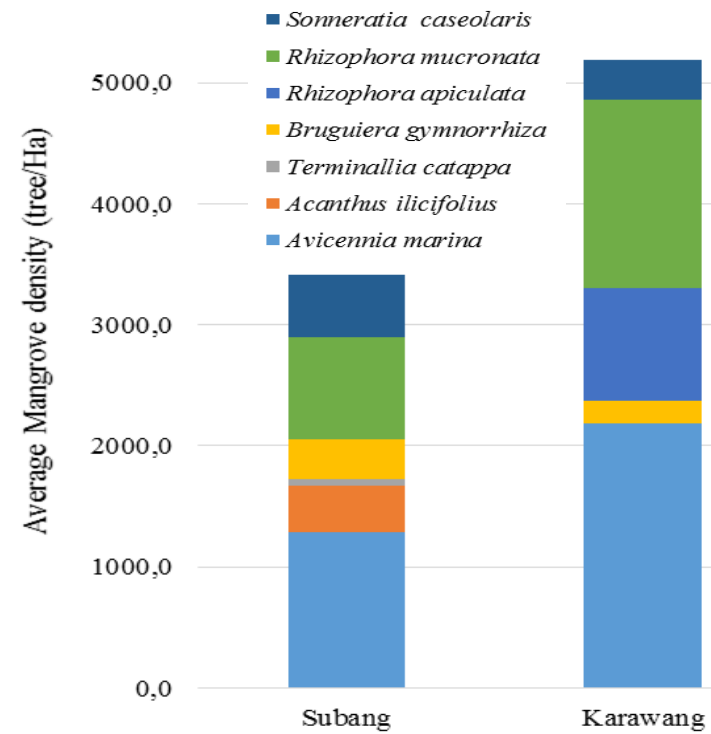

Figure 3. Average mangrove density (trees/Ha) in each station and total station (accumulative) in Blanakan, Subang and Tangkolak, Karawang, West Java, Indonesia

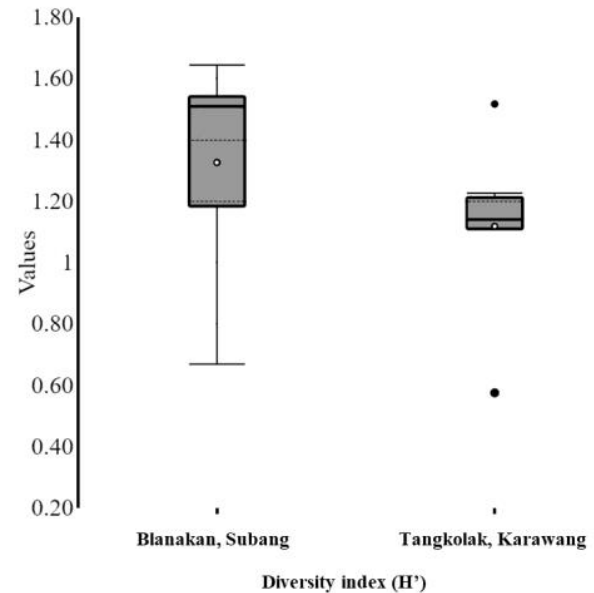

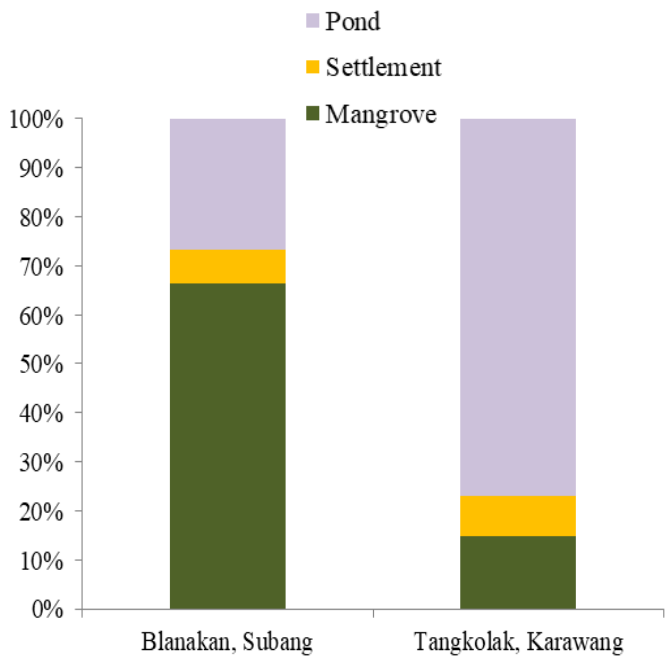

Figure 6. Restored mangrove and land cover compositions in Blanakan, Subang and Tangkolak, Karawang, West Java, Indonesia 

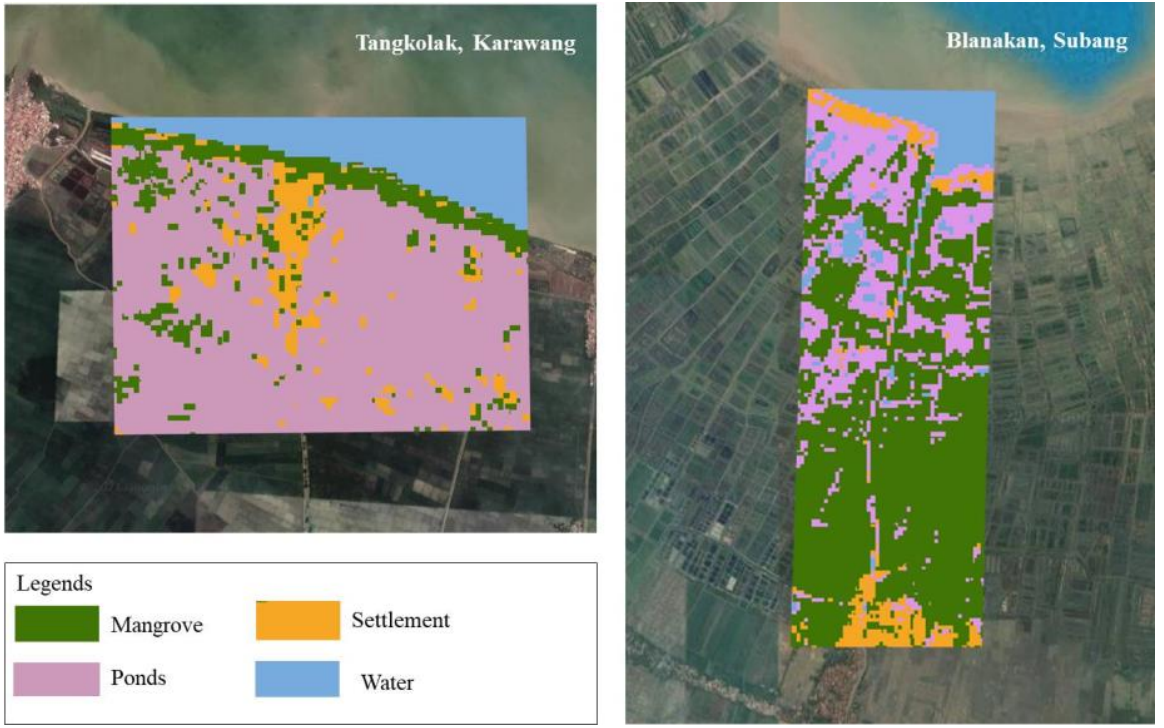

Figure 5. Restored mangrove and land cover distributions in Blanakan, Subang and Tangkolak, Karawang, West Java, Indonesia
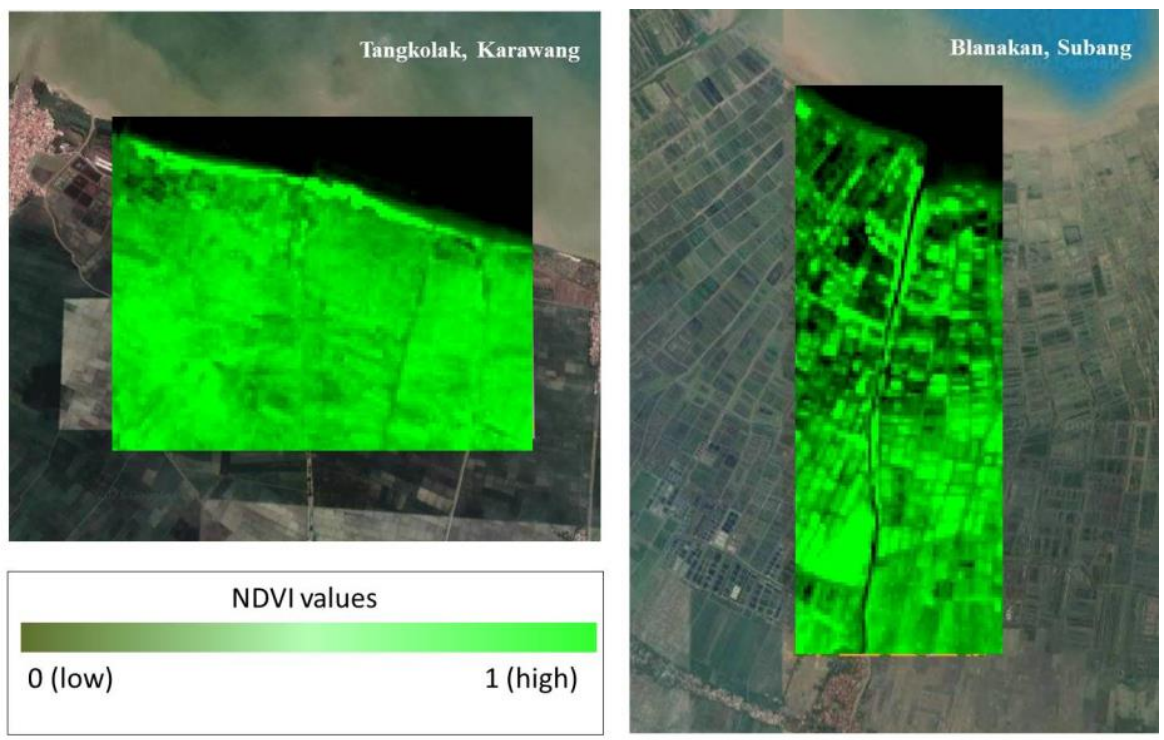

Figure 7. Mangrove NDVI values in Blanakan, Subang and Tangkolak, Karawang, West Java, Indonesia

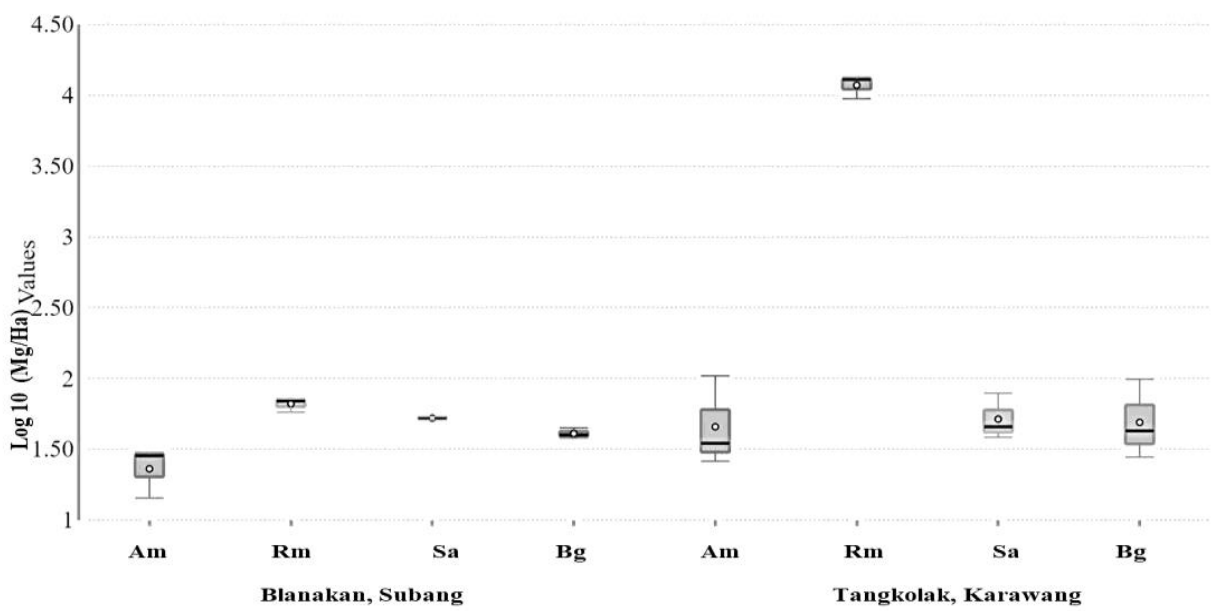

Figure 8. Mangrove biomass (log $10 \mathrm{mg} \mathrm{ha}^{-1}$ ) in Blanakan, Subang and Tangkolak, Karawang, West Java, Indonesia. (Am: Avicennia marina, Rm: Rhizophora mucronata, Sa: Sonneratia caseolaris, Bg: Bruguiera gymnorhiza) 
Table 2. Mangrove species and total numbers of trees in Blanakan, Subang and Tangkolak, Karawang, West Java, Indonesia

\begin{tabular}{lllccc}
\hline Family & Species & Local name & IUCN Redlist Status & Blanakan & Tangkolak \\
\hline Avicenniaceae & Avicennia marina & Api api & LC & 231 & 393 \\
Acanthaceae & Acanthus ilicifolius & Jeruju & LC & 69 & - \\
Combretaceae & Terminalia catappa & Ketapang & LC & 11 & - \\
Rhizophoraceae & Bruguiera gymnorhiza & Tancang & LC & 59 & - \\
& Rhizophora apiculata & Bakau & LC & 151 & 169 \\
Sonneratiaceae & Rhizophora mucronata & Bakau & LC & 94 & 515 \\
Total trees & & Pidada & & 615 & 534 \\
Grand total & & & & & 1549 \\
\hline
\end{tabular}

Note: IUCN Reldist Status: LC: least concern

Table 3. H' and D' values of mangrove locations of present study in comparison to other locations

\begin{tabular}{lcccl}
\hline Location & Numbers of species & $\mathbf{H}^{\prime}$ & $\mathbf{D}^{\prime}$ & Resources \\
\hline Blanakan, Subang & 6 & 1.326 & 0.650 & Present study \\
Tangkolak, Karawang & 5 & 1.063 & 0.577 & Present study \\
Banaybanay, Philippines & 33 & 3.145 & 0.056 & Pototan et al. (2021) \\
Panabo Park, Philippines & 5 & 1.027 & - & Alimbon and Manseguiao (2021) \\
Surabaya East Coast & 7 & 1.1 & 0.626 & Susanto et al. (2018) \\
Segara Anakan & 16 & 2.615 & - & Widyastuti et al. (2018) \\
\hline
\end{tabular}

Figure 7 presents the NDVI values of mangroves in Karawang and Subang. In Karawang, the NDVI clearly informed high NDVI values in the mangrove restoration areas. Whereas, the NDVI values were decreasing in the areas that were classified as settlements and ponds. In Subang, areas with NDVI values were more scattered. This condition considering that in Subang, restoration areas were mixed and combined with the fishponds.

\section{Mangrove biomass}

Comparison of mangrove biomass in Karawang and Subang restoration areas was presented in Figure 8. In Subang, the highest biomass was recorded in $R$. mucronata with average biomass of $72.32 \mathrm{mg} \mathrm{ha}^{-1}$ and the lowest was A. marina with value of $14.3 \mathrm{mg} \mathrm{ha}^{-1}$. R. mucronata species also had the highest biomass in Karawang with value of $1337.91 \mathrm{mg} \mathrm{ha}^{-1}$. A. marina was also observed to have the lowest biomass in Karawang with value of $26.05 \mathrm{mg} \mathrm{ha}^{-1}$.

\section{Discussion}

In this study, A. marina, R. apiculata, R. mucronata, and $S$. caseolaris were common mangroves and had high density. While B. gymnorhiza and A. ilicifolius were less common. This result was in line with other studies on mangrove communities (Table 3). Pototan et al. (2021) recorded that those species were having high frequencies and dominance. Susanto et al. (2018) have informed that in Surabaya East Coast, A. marina was the most common species. This could be because this species has a high tolerance limit to waters with extreme conditions, including high salinity and muddy substrate conditions, and unique root system known as pneumatophore. Avicennia can tolerate over a wide range of salinity compared to other genera of mangrove and this leads to A. marina adaptability to grow well in salinity close to $90 \%$. Two species of mangroves including $R$. apiculata and $R$. mucronata were more common in Karawang considering that most mangrove restoration programs in Southeast Asian countries mainly focused on planting common mangrove species such as Rhizophora sp. (Akbar et al. 2017). Rhizophora was preferred due to the ability of this species to protect coastal areas from erosion, high waves, and storms. Besides that, this species also possesses a higher capability to trap the sediment than other species and Rhizophora seedlings are easy to collect around restoration areas (Malik et al. 2020). The maximum richest taxa in genus and species levels observed in Rhizophoraceae (family of Rhizophora) considering that this family always has the richest taxa in most mangrove ecosystems in the world (Yessoufou and Stoffberg 2016) and as recorded in the present study, this family is referred to as the true mangrove family.

In Karawang there were two Rhizophora and in Subang only one Rhizophora species. This condition was also related to the restoration areas. According to Figure 5, restoration areas in Karawang were located in the coast. While in Subang, the restored areas were located in the fishponds and far from coasts. Restoration areas on the coast have mud substrate that is important for mangrove species to grow (Irawan et al. 2021). In this case, Rhizophora prefers to grow closest to the sea and inundated substrate conditions for long time.

According to Table 2, the diversity index of mangrove restoration areas was above $\mathrm{H}^{\prime}$ values in Panobo Park and Surabaya East Coast, whereas below H' values of Segara Anakan. Panabo Park and Surabaya were an open spaces meaning those locations can be accessed by the public. While Karawang and Subang were designated restored 
areas with limited access, this resulted in higher $\mathrm{H}^{\prime}$ values. Whereas, the comparisons with mangroves in Segara Anakan show $\mathrm{H}^{\prime}$ values in Karawang and Subang to be lower. Segara Anakan was protected areas and intact forests. In contrast, mangroves in Karawang and Subang resulted from mangrove seedlings initiated in 1990.

In terms of density, mangroves in Karawang had higher density than in Subang. Mangrove in Karawang resulted from restoration through mangrove planting program initiated by the community. Whereas the available areas designated for the mangrove restoration were narrow considering the land covers in Karawang were dominated by the ponds. Since the restoration was implemented in the limited space and mangrove planting has low planting spacing and mangrove seedlings were planted close to each other. In contrast, despite high density, mangroves in Karawang had lower diversity as indicated by lower $\mathrm{H}^{\prime}$ in comparison to mangrove in Subang, which may be due to plantation of less number of mangrove species in Karawang. Asuk et al. (2018) have identified several factors that may affect mangrove diversity in certain areas. Those factors include population growth, clearing for firewood and agriculture, and unsustainable extraction of nontimber forest products for food, local craft, and commerce. Mangrove forests located near settlements were more vulnerable to those activities that led to the diversity reductions. Settlements surrounded restoration areas in Karawang and this condition may explain the lower mangrove diversity in the Karawang.

High biomass of $R$. mucronata mainly found in Karawang indicated existence of old-age mangrove trees with high DBH, particularly resulting from good conservation practices of mangrove areas in Karawang. Higher biomass is ascribed to larger trunk diameter (mainly DBH) and tree height (Sheil et al. 2017; Scales and Friess 2019). Notably, the accounted aboveground living biomass of the study site can only be attributed to four species, namely (in order of contribution): $R$. mucronata, $S$. caseolaris, B. gymnorhiza, and A. marina. Out of the said four species, $R$. mucronata, was the most important, having the greatest contribution due to its stem diameter and biomass.

This study brings the results in showing differences in mangrove restoration patterns based on factors of density, index of diversity $\left(\mathrm{H}^{\prime}\right)$, biomass in coastal areas. Based on those factors, Karawang and Subang have different patterns. Karawang has lower $\mathrm{H}^{\prime}$ value but higher density and large biomass, while in Subang has higher $\mathrm{H}^{\prime}$ value but lower density and small biomass. Furthermore, this study confirmed that two species of $R$. mucronata and A. marina had higher biomass values compared to other species. The estimated value of restored mangroves in Subang and Karawang differs greatly based on the NDVI value. This research is expected to provide an overview of mangrove management. H' values observed in Karawang and Subang have indicated progress in mangrove restoration activities. While mangrove plantings combined with fishponds have also contributed to the areas of mangrove covers in Subang. Restoration of mangroves in both Karawang and Subang may have contributed to the mangrove assemblages in West Java Coasts.

\section{REFERENCES}

Akbar AA, Sartohadi J, Djohan TS, Ritohardoyo S. 2017. The role of breakwaters on the rehabilitation of coastal and mangrove forests in West Kalimantan, Indonesia. Ocean Coast Manag 138: 50-59. DOI: 10.1016/j.ocecoaman.2017.01.004

Alatorre LC, Sánchez-Carrillo S, Miramontes-Beltrán S, Medina RJ, Torres-Olave ME, Bravo LC, et al. 2016. Temporal changes of NDVI for qualitative environmental assessment of mangroves: Shrimp farming impact on the health decline of the arid mangroves in the Gulf of California (1990-2010). J Arid Environ 125: 98-109. DOI: 10.1016/j.jaridenv.2015.10.010

Alimbon JA, Manseguiao MRS. 2021. Species composition, stand characteristics, aboveground biomass, and carbon stock of mangroves in Panabo mangrove park, Philippines. Biodiversitas 22 (6): 31303137. DOI: $10.13057 /$ biodiv/d220615

Analuddin K, Sharma S, Jamili J, Septiana A, Sahidin I, Rianse U, Rahim S, Nadaoka K. 2018. Trends in allometric models and aboveground biomass of Rhizophoraceae mangrove family at the coral triangle ecoregion, Southeast Sulawesi, Indonesia. J Sustain For 37 (7): 691711. DOI: 10.1080/10549811.2018.1453843

Analuddin K, Kadidae LO, Haya LOMY, Septiana A, Sahidin I, Syahrir LA, Rahim S, Fajar LOA, Nadaoka K. 2020. Aboveground biomass, productivity and carbon sequestration in Rhizophora stylosa mangrove forest of Southeast Sulawesi, Indonesia. Biodiversitas 21 (4): 1316-1325. DOI: 10.13057/biodiv/d210407

Asuk SA, Offiong EE, Ifebueme NM, Akpaso EO. 2018. Species composition and diversity of mangrove swamp forest in southern Nigeria. Int $\mathbf{J}$ Avian Wildl Biol 3 (2): 159-164. DOI: 10.15406/ijawb.2018.03.00078

Clough BF, Scott K. 1989. Allometric relationships for estimating aboveground biomass in six mangrove species. For Ecol Manag 27 (2): 117-127. DOI: 10.1016/0378-1127(89)90034-0

Comley BWT, McGuinness KA. 2005. Above-and below-ground biomass, and allometry of four common northern Australian mangroves. Aus J Bot 53 (5): 431-436. DOI: 10.1071/BT04162

Dangan-Galon F, Dolorosa RG, Sespeñe JS, Mendoza NI. 2016. Diversity and structural complexity of mangrove forest along Puerto Princesa bay, Palawan island, Philippines. J Mar Isl Cult 5 (2): 118-125. DOI: 10.1016/j.imic.2016.09.001

Giri C, Ochieng E, Tieszen LL, Zhu Z, Singh A, Loveland T, Masek J, Duke N. 2011. Status and distribution of mangrove forests of the world using earth. Glob Ecol Biogeogr 20 (1): 154-159. DOI: 10.1111/j.1466-8238.2010.00584.x

Hanan AF, Pratikto I, Soenardjo N. 2020. Analisa distribusi spasial vegetasi mangrove di desa Pantai Mekar Kecamatan Muara Gembong. J Mar Res 9 (3): 271-280. DOI:10.14710/jmr.v9i3.27573 [Indonesian]

Ibharim NA, Mustapha MA, Lihan T, Mazlan AG. 2015. Mapping mangrove changes in the Matang Mangrove Forest using multitemporal satellite imageries. Ocean Coast Manag 114: 64-76. DOI: 10.1016/j.ocecoaman.2015.06.005

Irawan A, Chikmawati T, Sulistijorini. 2021. Diversity and zonation of mangrove flora in Belitung Island, Indonesia. Biodiversitas 22 (5): 2981-2992. DOI: $10.13057 /$ biodiv/d220563

IUCN 2021. The IUCN Red List of Threatened Species. Version 2021-1. https://www.iucnredlist.org

Kasim F, Kadim MK, Nursinar S, Karim Z, Lamalango A. 2019. Comparison of true mangrove stands in Dudepo and Ponelo islands, north Gorontalo District, Indonesia. Biodiversitas 20 (1): 259-266. DOI: 10.13057/biodiv/d200142

Kusmana C, Hidayat T, Tiryana T, Rusdiana O, Istomo. 2018. Allometric models for above-and below-ground biomass of Sonneratia spp. Glob Ecol Conserv 15: e00417. DOI: 10.1016/j.gecco.2018.e00417.

Malik A, Jalil AR, Arifuddin A, Syahmuddin A. 2020. Biomass carbon stocks in the mangrove rehabilitated area of Sinjai District, South Sulawesi, Indonesia. Geogr Environ Sustain 13 (3): 32-38. DOI: 10.24057/2071-9388-2019-131

Pototan BL, Capin NC, Delima AG, Novero AU. 2021. Assessment of mangrove species diversity in Banaybanay, Davao Oriental, 
Philippines. Biodiversitas 22 (1): 144-153. DOI: 10.13057/biodiv/d220120

Rahmayanti F, Nazira FK, Dewi AK, Oktaviani DF, Millaty INK, Prasetya TA, et al. 2018. Biodiversity of gastropod in the Sombu Beach, Wakatobi, Indonesia. In: Isnansetyo A, Puspita ID, Adzahan NM, Suadi, Sari DWK, Jayanti AD (eds), 2nd International Symposium on Marine and Fisheries Research, ISFMR 2017. Universitas Gadjah Mada, Yogyakarta, 24-25 July 2017. IOP Conf Ser: Earth Environ Sci 139: 012013. DOI: 10.1088/17551315/139/1/012013

Rhyma PP, Norizah K, Hamdan O, Faridah-Hanum I, Zulfa AW. 2020 Integration of normalised difference vegetation index and soiladjusted vegetation index for mangrove vegetation delineation. Remote Sens Appl: Soc Environ 17: 100280. DOI: 10.1016/j.rsase.2019.100280

Scales IR, Friess DA. 2019. Patterns of mangrove forest disturbance and biomass removal due to small-scale harvesting in southwestern Madagascar. Wetlands Ecol Manag 27 (5): 609-625. DOI: 10.1007/s11273-019-09680-5

Sheil D, Eastaugh CS, Vlam M, Zuidema PA, Groenendijk P, van der Sleen P, Jay A, Vanclay J. 2017. Does biomass growth increase in the largest trees? Flaws, fallacies and alternative analyses. Funct Ecol 31 (3): 568-581. DOI: 10.1111/1365-2435.12775

Sodikin, Sitorus SRP, Prasetyo LB, Kusmana C. 2017. Spatial analysis of mangrove deforestation and mangrove rehabilitation directive in
Indramayu Regency, West Java, Indonesia. AACL Bioflux 10 (6): 1654-1662.

Sreelekshmi S, Nandan SB, Kaimal SV, Radhakrishnan CK, Suresh VR 2020. Mangrove species diversity, stand structure and zonation pattern in relation to environmental factors-A case study at Sundarban delta, east coast of India. Reg Stud Mar Sci 35: 101111. DOI: 10.1016/j.rsma.2020.101111

Susanto AH, Soedarti T, Purnobasuki H. 2018. Mangrove community structure of Surabaya east coast. Vegetos 31: 09-12. DOI: 10.5958/2229-4473.2018.00085.X

Widyastuti A, Yani E, Nasution EK, Rochmatino. 2018. Diversity of mangrove vegetation and carbon sink estimation of Segara Anakan mangrove forest, Cilacap, Central Java, Indonesia. Biodiversitas 19 (1): 246-252. DOI: 10.13057/biodiv/d190133

Yessoufou K, Stoffberg GH. 2016. Biogeography, threats and phylogenetic structure of mangrove forest globally and in South Africa: A review. S Afr J Bot 107: 114-120. DOI: 10.1016/j.sajb.2015.11.002

Yudha RP, Sugito YS, Sillanpää M, Nurvianto S. 2021. Impact of logging on the biodiversity and composition of flora and fauna in the mangrove forests of Bintuni Bay, West Papua, Indonesia. For Ecol Manag 488: 119038. DOI: 10.1016/j.foreco.2021.119038

Zulhalifah, Syukur A, Santoso D, Karnan. 2021. Species diversity and composition, and above-ground carbon of mangrove vegetation in Jor bay, East Lombok, Indonesia. Biodiversitas 22 (4): 2066-2071. DOI: $10.13057 /$ biodiv/d220455. 